\title{
KANDUNGAN METABOLIT SEKUNDER DAN UJI AKTIVITAS DAUN PILA- PILA (Mallotus paniculatus)
}

\author{
Sri Indah Mulyawan Dewi ${ }^{1}$, Mirhansyah Ardana ${ }^{2}$, Laode Rijai ${ }^{3}$ \\ Laboratorium Penelitian dan Pengembangan FARMAKA TROPIS \\ Fakultas Farmasi Universitas Mulawarman, Samarinda Kalimantan Timur \\ *Email: sriindahmulyawandewi@gmail.com
}

\begin{abstract}
Pila-pila (Mallotus paniculatus) was a plant that widely used by dayak people to cure the fever, diarrhea, and itchy skin but there was no evidence showing the benefits of this plant, so the aims of this study were to determine the \% yield of extract, phytochemical content, the toxicity level of the pila-pila leaves against Artemia salina Leach, and antioxidant potency of the pila-pila leaves against DPPH (2,2-1-diphenyl-1picrylhydrazyl). The extraction method was done using maceration and methanol as a solvent, then toxicity assay and antioxidant activity were done using BSLT (Brine Shrimp Lethality Test) method with Reed and Muench to determine the Lethal Concentration $50 \%\left(L C_{50}\right)$ value and using DPPH method with linear regression to determine the Inhibition Concentration $50 \%$ (IC50) value. The Result of this study showed that \% yield of extract was $28.5 \%$ and methanol extract of the pila-pila leaves contains flavonoids, steroids, phenolics, and alkaloids. LC $C_{50}$ value of methanol extract of the pila-pila leaves was $320.19 \mathrm{mg} / \mathrm{L}$ with $r=0.999$ and $\mathrm{IC}_{50}$ value was $240.94 \mathrm{mg} / \mathrm{L}$ with $r=0.987$.
\end{abstract}

Keywords: BSLT, DPPH, Mallotus paniculatus.

\begin{abstract}
ABSTRAK
Tumbuhan pila-pila (Mallotus paniculatus) adalah tumbuhan yang banyak digunakan oleh masyarakat suku dayak untuk mengatasi demam, diare, dan gatal-gatal pada kulit namun belum ada bukti ilmiah yang menunjukkan manfaat dari tumbuhan ini secara pasti di Indonesia sehingga penelitian ini bertujuan untuk mengetahui rendemen ekstrak, golongan metabolit sekunder, potensi toksisitas daun pila-pila terhadap Artemia salina Leach, dan potensi antioksidan daun pila-pila terhadap DPPH (2,2-difenil-1-pikrilhidrazil). Penelitian ini menggunakan metode maserasi dengan pelarut metanol untuk mengekstraksi daun pilapila, metode BSLT (Brine Shrimp Lethality Test) serta analisis Reed and Muench untuk mengetahui nilai $\mathrm{LC}_{50}$ dan menggunakan metode peredaman terhadap DPPH serta analisis regresi linier untuk mengetahui nilai $\mathrm{IC}_{50}$ pada ekstrak metanol daun pila-pila. Hasil rendemen ekstrak adalah $28.5 \%$ dan hasil identifikasi golongan metabolit sekunder ekstrak metanol daun pila-pila yaitu flavonoid, steroid, fenolik, dan alkaloid. Nilai $\mathrm{LC}_{50}$ ekstrak metanol daun pila-pila adalah 320,19 ppm dengan nilai $\mathrm{r}=0,999$ dan nilai $\mathrm{IC}_{50}$ ekstrak metanol daun pila-pila adalah 240,94 ppm dengan nilai $r=0,987$.
\end{abstract}

Kata Kunci: BSLT, DPPH, Mallotus paniculatus. 


\title{
PENDAHULUAN
}

Indonesia merupakan salah satu pusat penyebaran tumbuhan tropika dan termasuk satu dari tujuh negara megadiversity yang kaya akan keanekaragaman hayati. Oleh karena itu, setiap spesies tumbuhan, hewan, mikroorganisme yang terdapat di laut maupun di darat mempunyai nilai-nilai kimiawi dalam arti menghasilkan bahan-bahan kimia yang banyak jumlahnya. Salah satu tumbuhan Indonesia yang berasal dari Kalimantan Timur dan berpotensi sebagai bahan obat tradisional adalah pila-pila (Mallotus paniculatus). Tumbuhan pila-pila secara empiris digunakan untuk mengatasi demam, diare, dan gatalgatal pada kulit oleh suku dayak di Kalimantan Timur. Namun belum ada penelitian yang dilakukan terhadap tumbuhan pila-pila karena penggunaannya sebagai bahan obat di kalangan suku dayak masih belum diketahui oleh masyarakat luas sehingga perlu dilakukan pengujian dasar untuk menentukan bioaktivitas dan aktivitas antioksidan dari tumbuhan ini.

Untuk mengidentifikasi senyawa antioksidan dapat menggunakan senyawa 2,2difenil-1-pikrilhidrazil (DPPH) atau lebih dikenal dengan nama metode DPPH. Senyawa radikal kromogen seperti DPPH dapat secara langsung bereaksi dengan antioksidan. DPPH digunakan untuk mengevaluasi kemampuan antioksidan dari komponen dengan mengukur perubahan absorbansi, absorbansi DPPH akan menurun apabila elektron ganjil dari atom hidrogen dalam DPPH direduksi dengan penerimaan sebuah atom hidrogen dari antioksidan. Pengukuran aktivitas antioksidan dapat diketahui berdasarkan nilai Inhibisi Concentration (IC) 50, di mana menunjukkan kemampuan senyawa menghambat proses oksidasi sebesar $50 \%{ }^{[3]}$.

Pengujian toksisitas dapat dilakukan dengan menggunakan metode Brine Shrimp Lethality Test (BSLT). BSLT merupakan metode untuk mengetahui tingkat toksisitas suatu senyawa aktif terhadap larva udang Artemia salina. Senyawa aktif yang memiliki daya toksisitas tinggi diketahui berdasarkan nilai Lethal Concetration 50\% ( $\left.\mathrm{LC}_{50}\right)$, yaitu suatu nilai yang menunjukkan konsentrasi zat toksik yang menyebabkan kematian hewan uji sebesar 50\%. Hasil uji toksisitas dapat dijadikan tolak ukur penggunaan konsentrasi senyawa aktif yang aman untuk digunakan ${ }^{[2]}$.

\section{METODOLOGI PENELITIAN}

Penelitian ini dilaksanakan pada bulan Agustus hingga bulan Oktober 2016 di Penelitian dan Pengembangan FARMAKA TROPIS Fakultas Farmasi Universitas Mulawarman, Samarinda Kalimantan Timur.

Penelitian ini di lakukan dengan cara observasi lapangan dan dilanjutkan dengan analisis laboratorium dan eksperimen. Daun pila-pila (Mallotus paniculatus) di ambil dari daerah Desa Royoq, Kutai Barat Kalimantan Timur. Daun ini kemudian dibersihkan dari kotoran, dikeringanginkan, dihaluskan dan ditimbang. Sampel yang telah halus di maserasi dengan pelarut metanol. Kemudian ekstrak metanol daun pila-pila diuji fitokimia dan uji potensi toksisitas dengan menggunakan larva udang (brine shrimp lethality test), serta uji potensi antioksidan dengan menggunakan metode peredaman radikal bebas 2,2-difenil-1pikrilhidrazil (DPPH) dengan menggunakan spektrofotometer UV-Vis.

\begin{abstract}
Alat
Alat-alat yang digunakan dalam penelitian ini yaitu, gelas kimia, timbangan analitik, rotary evaporator, pipet ukur, pipet tetes, rak tabung, tabung reaksi, mikropipet, hot plate, batang pengaduk, magnetik stirer, labu ukur, corong porselin, corong kaca, gunting, spatula, aquarium, aerator, lampu pijar, spektrofometer $u v$-visible, botol reagent, botol vial, desikator, spektrofotometer UV-Vis, kamera digital, alat tulis.
\end{abstract}




\section{Bahan}

Bahan-bahan yang digunakan adalah daun pila-pila (Mallotus paniculatus) metanol, aquadest, aseton, $\mathrm{FeCl}_{3}, \mathrm{H}_{2} \mathrm{SO}_{4}$ pekat, serbuk $\mathrm{Mg}$, reagen dragendorf, amoniak, $\mathrm{H}_{2} \mathrm{SO}_{4} 2 \mathrm{M}$, $\mathrm{CH}_{3} \mathrm{COOH}$ glasial, $\mathrm{Bi}\left(\mathrm{NO}_{3}\right)_{2} .5 \mathrm{H}_{2} \mathrm{O}, \mathrm{HgCl}_{2}, \mathrm{HNO}_{3}$ pekat, $\mathrm{KI}, \mathrm{FeCl}_{3} 1 \%, \mathrm{HCl}$ pekat, serbuk $\mathrm{Mg}$, air laut, ragi, naupli Artemia salina, aluminium foil, kertas saring, plastik perekat, kertas label, tisu, DPPH, tween 80.

\section{Preparasi Sampel}

Daun pila-pila (Mallotus paniculatus) yang diambil di Desa Royoq, Kutai Barat Kalimantan Timur dibersihkan, kemudian dikeringanginkan tanpa terkena sinar matahari secara langsung. Setelah sampel kering kemudian dihaluskan.

\section{Ekstraksi Senyawa Metabolit Sekunder}

Sampel daun pila-pila (Mallotus paniculatus) yang telah dihaluskan, ditimbang kemudian diekstraksi dengan metode maserasi menggunakan pelarut metanol, diekstraksi sampai larutan ekstrak tidak berwarna lagi. Filtrat yang diperoleh kemudian disaring dengan corong porselin dan dipekatkan dengan rotary evaporator sampai didapatkan ekstrak yang lebih pekat.

\section{Uji Metabolit Sekunder}

Uji metabolit sekunder ini meliputi uji flavonoid, uji fenolik, uji alkaloid, uji saponin, uji steroid dan triterpenoid.

\section{Uji Potensi Toksisitas dengan Metode BSLT (Brine Shrimp Lethality Test)}

Uji potensi toksisitas dilakukan dengan metode BSLT menggunakan larva udang Artemia salina. $100 \mathrm{mg}$ larva udang ditetaskan dalam air laut sebanyak $200 \mathrm{~mL}$ dan diberi penerangan serta diaerasi selama 48 jam. Setelah telur menetas disiapkan larutan uji ekstrak metanol daun pila-pila dengan konsentrasi 100, 200, 300, 400, $500 \mathrm{mg} / \mathrm{L}$ dengan penambahan tween 80 untuk meningkatkan kelarutan ekstrak dalam air laut. Sebanyak 10 $\mathrm{mL}$ air laut yang mengandung larva udang sebanyak 10 ekor dipipet dan dimasukan ke dalam wadah uji. Ditambahkan larutan sampel yang akan diuji masing-masing ke dalam wadah uji. Larutan kontrol dibuat tanpa penambahan sampel. Larutan dibiarkan selama 24 jam, kemudian dihitung jumlah larva yang mati dan yang hidup dari tiap wadah uji, kemudian analisa dengan menggunakan Reed and Muench untuk menentukan nilai $\mathrm{LC}_{50}$.

\section{Uji Potensi Antioksidan dengan Metode DPPH (2,2-difenil-1-pikrilhidrazil)}

Larutan DPPH dibuat dengan konsentrasi $40 \mathrm{mg} / \mathrm{L}$ dan ditambahkan sebanyak $2 \mathrm{~mL}$ kedalam tabung reaksi yang berisi $2 \mathrm{~mL}$ ekstrak daun pila-pila dengan konsentrasi 100, 150, 200, 250, dan $300 \mathrm{mg} / \mathrm{L}$ lalu divortex selama 2 menit. Berubahnya warna ungu menjadi warna kuning menunjukan adanya aktivitas antioksidan. Diukur absorbansi pada spektrofotometer UV-Vis dengan panjang gelombang $516.2 \mathrm{~nm}$ setelah larutan diinkubasi selama 30 menit. Kemudian data dianalisis dengan menggunakan regresi linier.

\section{HASIL DAN PEMBAHASAN}

\section{Preparasi Sampel}

Daun pila-pila yang telah dipetik, dicuci untuk menghilangkan kotoran yang dapat mengganggu seperti debu dan tanah. Kemudian di potong kecil-kecil agar sampel lebih cepat kering dan dikeringanginkan tanpa terkena sinar matahari. Pengeringan bertujuan untuk mengurangi kadar air, mencegah tumbuhnya jamur sehingga dapat disimpan lebih lama dan senyawa kimia yang ada dalam sampel tidak mudah rusak. 
Sampel yang telah kering, dihaluskan dengan cara diayak hingga menjadi potongan yang lebih kecil (simplisia). Pembuatan simplisia dengan ukuran yang lebih kecil ini dapat mempermudah proses ekstraksi. kehalusan bahan mempengaruhi rendemen ekstrak yang dihasilkan. Semakin halus bahan yang digunakan, maka akan semakin tinggi rendemen yang dihasilkan, dimana permukaan dari sampel semakin luas sehingga memperbesar terjadinya kontak antara partikel sampel dengan pelarut.

\section{Rendemen Ekstrak}

Simplisia daun pila-pila diekstraksi dengan metode maserasi. Sebanyak $60 \mathrm{~g}$ simplisia daun pila-pila dimaserasi dengan pelarut metanol sebanyak $1200 \mathrm{~mL}$. Digunakan metode maserasi ini karena memiliki keuntungan yaitu didapatkan ekstrak yang banyak serta dapat menghindarkan perubahan kimia terhadap senyawa-senyawa tertentu oleh karena pemanasan. Maserasi dilakukan 1 kali 24 jam kemudian disaring dan didapatkan filtrat. Dilakukan remaserasi sebanyak 5 kali agar senyawa kimia yang terkandung dalam sampel dapat tertarik secara maksimal. Kemudian filtrat dipekatkan dengan menggunakan rotary evaporator untuk mendapatkan ekstrak yang pekat.

Berdasarkan hasil ektraksi daun pila-pila maka diketahui jumlah randemen sampel yaitu $28.5 \%$. Dimana berat ekstrak $17.1 \mathrm{~g}$ dan berat simplisia daun pila-pila sebesar $50 \mathrm{~g}$.

\section{Uji Metabolit Sekunder}

Berdasarkan hasil uji metabolit sekunder terhadap ekstrak metanol daun pila-pila terdapat senyawa alkaloid, fenolik, flavonoid, dan steroid. Hasil pengujian dapat dilihat pada Tabel 1.

Tabel 1. Golongan Metabolit Sekunder

\begin{tabular}{ccc}
\hline No. & Golongan Senyawa & Hasil \\
\hline 1 & Alkaloid & + \\
2 & Fenolik & + \\
3 & Flavonoid & + \\
4 & Saponin & - \\
5 & Steroid & + \\
\hline
\end{tabular}

\section{Uji Potensi Toksisitas dengan Metode BSLT (Brine Shrimp Lethality Test)}

Pengujian potensi toksisitas yang dilakukan dengan metode BSLT (Brine Shrimp Lethality Test) menggunakan larva udang Artemia salina. Kemampuan toksisitas ekstrak metanol dari daun pila-pila dalam mematikan larva udang yang telah diberi perlakuan dengan konsentrasi 100, 200, 300, 400, dan 500 mg/L dapat dilihat dalam Tabel 2.

Tabel 2. Pesentase Jumlah Kematian Larva Udang

\begin{tabular}{cccccccc}
\hline \multirow{2}{*}{$\mathbf{C}$} & \multirow{2}{*}{ Log C } & \multicolumn{2}{c}{ Jumlah } & \multicolumn{2}{c}{ Akumulasi } & Rasio & \begin{tabular}{c} 
Mortalitas \\
\cline { 3 - 6 } $\mathbf{( \% )}$
\end{tabular} \\
\cline { 3 - 6 } & Mati & Hidup & $\mathbf{x}$ & $\mathrm{y}$ & $\mathbf{x})$ & 6.75 \\
$100 \mathrm{ppm}$ & 2 & 10 & 40 & 10 & 138 & 0.0675 & 24.03 \\
$200 \mathrm{ppm}$ & 2.301 & 21 & 29 & 31 & 98 & 0.2403 & 43.44 \\
$300 \mathrm{ppm}$ & 2.477 & 22 & 28 & 53 & 69 & 0.4344 & 65.83 \\
$400 \mathrm{ppm}$ & 2.602 & 26 & 24 & 79 & 41 & 0.6583 & 66.82 \\
$500 \mathrm{ppm}$ & 2.698 & 33 & 17 & 112 & 17 & 0.8688 & \\
\hline
\end{tabular}


Berdasarkan tabel 2 terlihat semakin tinggi konsentrasi ekstrak maka semakin besar tingkat kematian larva udang, dimana tingkat kematian tertinggi terdapat pada konsentrasi $500 \mathrm{mg} / \mathrm{L}$, sedangkan kematian terendah terdapat pada konsentrasi $100 \mathrm{mg} / \mathrm{L}$. Tingkat kematian dapat ditemukan secara langsung melalui perbandingan konsentrasi yang berkisar dari konsentrasi terendah hingga konsentrasi tertinggi. Dengan kata lain, kematian larva udang disebabkan oleh peningkatan konsentrasi dalam sampel.

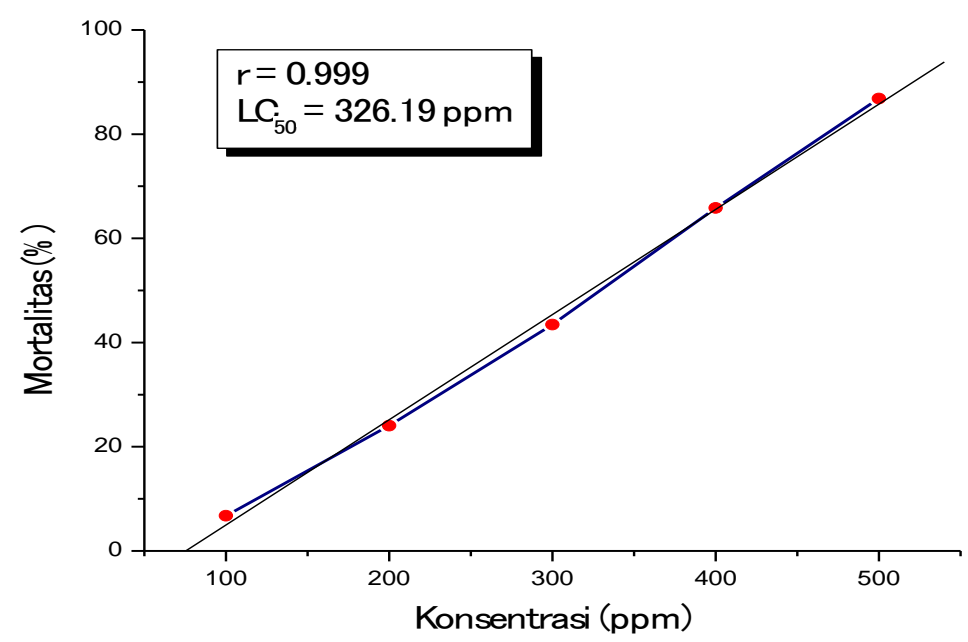

Gambar 1. Grafik Potensi Toksisitas terhadap Artemia salina Leach

Suatu ekstrak daun bersifat toksik apabila mempunyai nilai $\mathrm{LC}_{50}<1000 \mathrm{mg} / \mathrm{L}$. $\mathrm{LC}_{50}$ yaitu konsentrasi yang dapat mematikan 50\% larva udang laut. Berdasarkan hasil pengujian dengan menggunakan analisis Reed and Muench didapatkan nilai $\mathrm{LC}_{50}$ dari esktrak metanol daun pila-pila yaitu $326.19 \mathrm{mg} / \mathrm{L}$. Hal ini menunjukkan bahwa ekstrak metanol daun pilapila memiliki sifat toksik, dimana nilai $\mathrm{LC}_{50}<1000 \mathrm{mg} / \mathrm{L}$.

Menurut Meyer (1982), kematian larva A. salina disebabkan keberadaan senyawa metabolit sekunder yang bersifat toksik, ketika senyawa tersebut tertelan oleh larva, maka akan menyebabkan efek antifeedant yang membuat larva $A$. salina tidak bisa makan, sehingga menyebabkan larva $A$. salina akan mati.

\section{Uji Potensi Antioksidan dengan Metode DPPH (2,2-difenil-1-pikrilhidrazil)}

Pengujian aktivitas antioksidan pada ekstrak etanol daun pila-pila dilakukan dengan menggunakan metode DPPH. Hasil pengujian DPPH dapat dilihat pada Gambar. 2. 


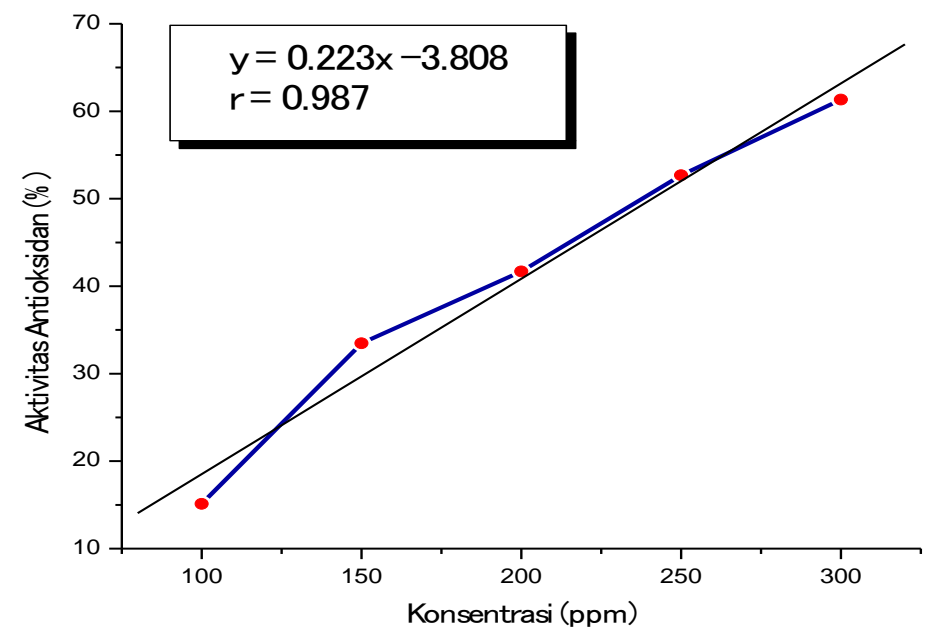

Gambar 2. Grafik Potensi Antioksidan Ekstrak Metanol Daun Pila-Pila

Larutan DPPH yang awalnya berwarna ungu setelah bereaksi dengan antioksidan alami akan membentuk warna kuning. Semakin tinggi kandungan antioksidan maka warna ungu pada larutan DPPH akan semakin berkurang dan membentuk warna kuning. Pemudaran warna akan mengakibatkan penurunan nilai absorbansi sinar tampak dari spektofotometer ${ }^{[3]}$. Pada prinsipnya uji aktivitas antioksidan dengan metode DPPH dilakukan berdasarkan kemampuan antioksidan untuk menghambat radikal bebas dengan mendonorkan atom hidrogen kepada DPPH, sehingga DPPH yang telah berpasangan dengan atom hidrogen tersebut akan menghasilkan DPPH yang tereduksi.

Pada pengujian DPPH diperoleh \% Inhibisi atau aktivitas antioksidan yang dimiliki oleh ekstrak daun pila-pila tertinggi pada konsentrasi $300 \mathrm{mg} / \mathrm{L}$ yakni 61.33\%. Berdasarkan perubahan warna yang terjadi dapat diketahui bahwa ekstrak daun pila-pila memiliki aktivitas antioksidan yang sangat lemah, hal ini ditunjukkan dengan warna yang berubah pada larutan uji terjadi secara perlahan dan tidak mencapai perubahan warna ungu ke warna kuning, melainkan hanya memudar pada konsentrasi $300 \mathrm{mg} / \mathrm{L}$. Kemampuan aktivitas antioksidan eksrtrak daun pila-pila ini juga dibuktikan dengan nilai IC $_{50}$ yang sebesar 240.94 mg/L. Nilai ini didapat dengan menghitung persamaan linear dari gambar 2.

\section{KESIMPULAN}

Berdasarkan hasil penelitian yang telah dilakukan dapat disimpulkan bahwa ekstrak metanol daun pila-pila (Mallotus paniculatus) memiliki rendemen sebesar $28.5 \%$ dengan kandungan metabolit sekunder berupa alkaloid, fenolik, flavonoid, dan steroid. Ekstrak metanol daun pila-pila memiliki nilai $\mathrm{LC}_{50}$ sebesar $326.19 \mathrm{mg} / \mathrm{L}$ dan $\mathrm{IC}_{50}$ sebesar 240.94 $\mathrm{mg} / \mathrm{L}$ sehingga berdasarkan nilai $\mathrm{LC}_{50}$ dan $\mathrm{IC}_{50}$ ekstrak daun pila-pila memiliki potensi sebagai pestisida dan sangat lemah sebagai antioksidan.

\section{DAFTAR PUSTAKA}

Abdu, Z., Dimas, K., Sunday, A.O., Isyaka, M.S., Sa'id, J. 2016. Qualitative Investigation of Pythochemicals and Brine Shrimp Lethality Test of The Root, Stem Bark, and Leaves Extract of Isoberlinia doka (Fabaceae). International Journal of Chemical Studies. Vol. 4, No.1. 
Meyer, B. N. Ferrigni, Putnam, J. E. Jacobsen, L. B. Nichols, Mclaughin. 1982. Brine Shrimp: A Cowenient General Bioassay for Active Plant Constituenls. Planta Medica. 45:31-34.

Molyneux, Philip. 2004. The Use of The Stable Free Radical diphenylpicrylrydrazyl (DPPH) for Estimating Antioxidant Activity. Songklanaklarin Journal Science Technology. 26(2):211-219.

Xie, J., dan Schaich, K.M. 2014. Re-evaluation of the 2,2-Diphenyl-1-Picrylhydrazyl Free Radical (DPPH) Assay for Antioxidant Activity. Journal of Agricultural and Food Chemistry. Vol. 62. 